\title{
Sellar Germinoma
}

National Cancer Institute

\section{Source}

National Cancer Institute. Sellar Germinoma. NCI Thesaurus. Code C155802.

A germinoma that arises from or adjacent to the sellar region. 